\title{
FORAGE YIELD AND QUALITY OF QUINOA (Chenopodium quinoa Willd.) GENOTYPES HARVESTED AT DIFFERENT CUTTING STAGES UNDER MEDITERRANEAN CONDITIONS
}

\author{
Saban YILMAZ ${ }^{1}$, Ibrahim ERTEKIN ${ }^{*}$, Ibrahim ATIS \\ ${ }^{1}$ Hatay Mustafa Kemal University, Faculty of Agriculture, Department of Field Crops, Hatay, TURKEY \\ *Corresponding author: ibrahim.ertkn@hotmail.com
}

Received: 25.08.2021

\begin{abstract}
Genotype choosing and cutting stage are very significant to obtained better forage yield and quality. However, researches about forage production from quinoa plant genotypes harvested at different cutting stages are not enough in Mediterranean conditions. This study was conducted to determine the forage yield and quality of five different quinoa genotypes (Red head, Cherry vanilla, French vanilla, Mint vanilla and Titicaca) at three different cutting stages (flowering, milky and dough). The experiment was laid out in split plot of randomized complete blocks with three replications in 2019 and 2020 years. To evaluate the forage yield and quality of different quinoa genotypes harvested at different cutting stages, plant height, stem diameter, dry forage yield, dry matter content, water soluble carbohydrate, neutral detergent fiber, acid detergent fiber, acid detergent lignin, condensed tannins, ether extract, crude protein, crude ash, organic matter, non-fiber carbohydrate and relative feed value properties were investigated. As a result of the research, it was determined that it is appropriate to harvest quinoa as a roughage source at the dough stage, and that Mint vanilla genotype is the most productive genotype.
\end{abstract}

Keywords: Cutting date, forage quality, genotype, quinoa, yield

\section{INTRODUCTION}

Quinoa (Chenopodium quinoa Willd.) is a one-year plant from Amaranthaceae family and has spread to the World from the Andhes Mountains in South America. This plant that known in recent years in Turkey has been cultivated by indigenous people for thousands of years in South America (Vega-Galvez et al., 2010). Quinoa is a pseudo-cereal from the South American region where this plant is used principally for human nutrition. Also, the plant can be used as roughage in livestock (Rosero et al., 2010; Liu et al., 2020). Fast and easy growing quinoa can be alternative forage crop and use animal feeding in Turkey (Bazile et al., 2015; Tan and Temel, 2019).

Many researches about quinoa plants have been conducted recently in Turkey. While some of these studies were on seed yield (Geren et al., 2014; Geren et al., 2015; Geren, 2015; Kir and Temel, 2016; Dumanoglu et al., 2016; Geren and Gure, 2017), some were carried out on the forage yield and quality of quinoa (Tan and Temel, 2017; Tan and Temel, 2019; Temel and Surgun, 2019; Kaya and Kizil Aydemir, 2020; Tan and Temel, 2020; Temel and Tan, 2020). All of the studies on forage yield and quality mentioned above were carried out in regions representing continental climatic conditions. In the literature, we did not find any study conducted to determine the feed yield and quality in Mediterranean conditions in Turkey. In addition, in this study, a more comprehensive assessment was tried to be made on forage quality.

Forage yield and quality of many forage crops vary greatly depending on cutting stage (Atis et al., 2012). Previous studies have indicated that when quinoa is harvested at suitable time, higher nutrient for animals can be obtained (Bazile et al., 2015). It was reported that it can be more suitable for animal feeding because low fiber and high protein can be obtained when quinoa plant is cut in flowering stage (Tan and Temel, 2019). Although the forage yield and quality of different quinoa plants were investigated changing of forage yield and quality of this plant according to cutting stage are not discovered with an extensive work in Mediterranean condition of Turkey.

Therefore, this study was conducted to determinate the effect of harvest times on forage yield, yield components, chemical compositions and nutritive value of different quinoa genotypes in Mediterranean conditions.

\section{MATERIALS AND METHODS}

This study was carried out at the Hatay Mustafa Kemal University Agricultural Faculty Experimental Area located Reyhanl, Hatay $\left(36^{\circ} 15^{\prime} 13.56^{\prime \prime} \mathrm{N} 36^{\circ} 30^{\prime} 7.96^{\prime \prime} \mathrm{E}\right.$, 
altitude $96 \mathrm{~m}$ above sea level) in 2019 and 2020 growing seasons. The experimental soil property was clay loam with pH 7.12 (slightly alkaline), organic matter $1.93 \%$ (low), P $7.41 \mathrm{mg} \mathrm{kg}^{-1}$ soil (moderate), lime $6.45 \%$ (moderate) and total salt $0.0078 \%$ (low). When climatic data (Figure 1) were investigated, means of temperature value of growing season of 2019 and 2020 were recorded as $21.9{ }^{\circ} \mathrm{C}$ and $22.2{ }^{\circ} \mathrm{C}$ and total precipitation amounts $162.4 \mathrm{~mm}$ and $101.8 \mathrm{~mm}$, respectively.

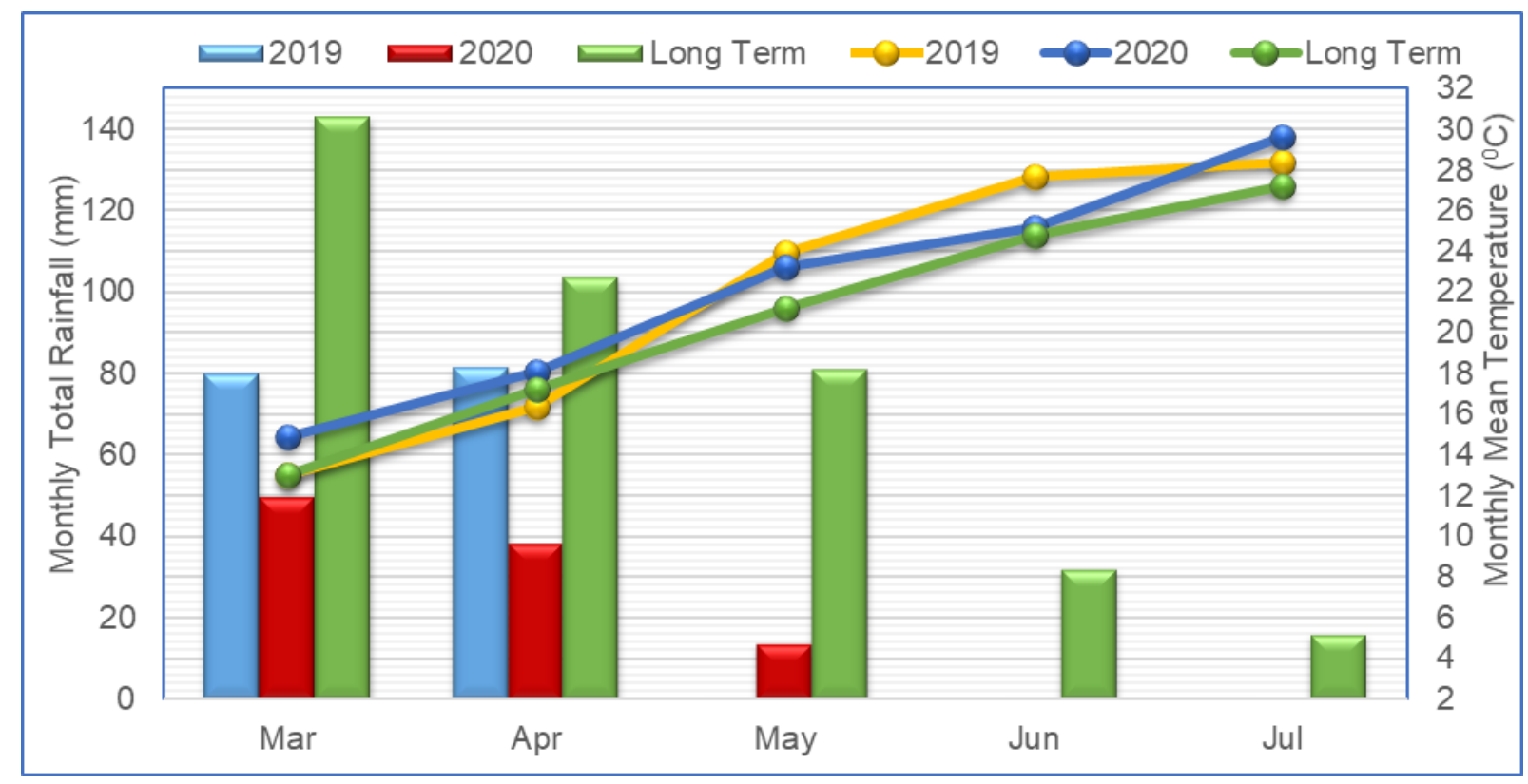

Figure 1. Monthly means of air temperature and total rainfall during March to July in 2019 and 2020 and 79-year average (19402019) at Hatay, Turkey.

The experiment was laid out in a split plot design in randomized block design with three replicates, three main plots (cutting stages; flowering, milky and dough stages) and five sub-plots (genotypes; Mint vanilla, Cherry vanilla, French vanilla, Red head and Titicaca). For all three cutting stages, quinoa plants were harvested about 75, 90 and 105 days after first emergence of seedlings. Each sub-plots had 7 rows with $25 \mathrm{~cm}$ row spacing and 4 $\mathrm{m}$ row length. Sowing was performed by hand on 25 March 2019 and 27 March 2020. Seeding rate was $10 \mathrm{~kg}$ $\mathrm{ha}^{-1}$. Before planting, the soil was fertilized with $60 \mathrm{~kg} \mathrm{ha}^{-}$ ${ }^{1} \mathrm{~N}, \mathrm{P}_{2} \mathrm{O}_{5}$ and $\mathrm{K}_{2} \mathrm{O}$ and when the plants reached the $50 \mathrm{~cm}$ in height they were fertilized with $60 \mathrm{~kg} \mathrm{da}^{-1} \mathrm{~N}$ as urea. Plants were irrigated three times on 15 May and 30 May and 15 June in both years with a drip irrigation system.

At each cutting stage, harvest and sampling procedures were made at the center five rows of each plot. Plant heights (PH) and stem diameters (SD) were measured of ten plants randomly selected before harvest. Plants were cut to a stubble height of approximately $5 \mathrm{~cm}$. After measuring fresh forage weights, fresh plants were chopped with a chopping machine (CAN SP255, CANTEK MAKINE, Sinop, Turkey) and a $500 \mathrm{~g}$ subsample taken from chopped samples was dried in a forceddraft oven to constant weight at $65^{\circ} \mathrm{C}$ for chemical analysis and calculation of dry forage yield (DFY).

Samples that dried at $65{ }^{\circ} \mathrm{C}$ for 48 hours in dryingoven were milled to pass a $1 \mathrm{~mm}$ sieve for chemical analysis. Dry matter (DM) contents of quinoa genotypes were determined by drying-oven at $105{ }^{\circ} \mathrm{C}$ for 24 hours.
Crude ash (CA) contents were investigated by burning in the muffle furnace at $550{ }^{\circ} \mathrm{C}$ for 4 hours (AOAC, 2019). Nitrogen contents of samples were measured by the Kjeldahl method (AOAC, 2019). Crude protein (CP) contents were calculated as $\mathrm{N} \times 6.25$. Ether extract (EE) contents were examined using soxhlet extractor according to the AOAC (2019). NDF, ADF and ADL were analyzed according to the sequential method of Van Soest et al. (1991) by using the ANKOM filter bag system with A220 fiber analyzer (ANKOM Technology Corp., Fairport, NY, USA). Non-Fiber carbohydrate (NFC) was estimated by using the equation $\mathrm{NFC}=100-(\mathrm{NDF}+\mathrm{CP}+\mathrm{EE}+\mathrm{CA})(\mathrm{NRC}$, 2001). Condensed tannin (CT) contents were analyzed by the method of Makkar et al. (1999). Water soluble carbohydrate (WSC) was determined according to the phenol-sulfuric acid method (Dubois et al., 1956). Relative feed value (RFV) was calculated by the following formulas developed by Van Dyke and Anderson (2002). Before calculating the RFV, digestible dry matter (DDM) and dry matter intake (DMI) were numbered by taking advantage of NDF and ADF values.

(1) $\mathrm{DDM} \%=88.9-(0.779 \times \mathrm{ADF} \%)$;

(2) $\mathrm{DMI} \%=120 / \mathrm{NDF} \%$; (3) $\mathrm{RFV}=\mathrm{DDM} \times \mathrm{DMI} \times 0.775$

Where, DDM is \% of dry matter, DMI is \% of animal body weight

\section{Statistical analyses}

A combined analysis of variance over 2 years was performed. Variance analyses (ANOVA) for all values 
obtained from present study were made according to the split-plot in randomized block design. Significance among the means was evaluated by using the TUKEY pairwise test $(p<0.05)$ (Steel and Torrie, 1980).

\section{RESULTS AND DISCUSSION}

\section{Yield and yield components}

Effects of years, cutting stages (CS) and quinoa genotypes $(\mathrm{G})$ on plant height $(\mathrm{PH})$ and stem diameter (SD) were statistically significant but interactions were insignificant (Table 1). An increase in plant height was recorded as maturity prolonged for quinoa cultivars. The $\mathrm{PH}$ values among the cutting stages ranged from 121.98 to $135.84 \mathrm{~cm}$. The highest $\mathrm{PH}$ was determined in dough stage while the lowest that in flowering stage. $\mathrm{PH}$ values among the genotypes varied between 114.08 to 136.26 $\mathrm{cm}$. Plant heights of Cherry vanilla, French vanilla and Mint vanilla were statistically similar. Plant heights of those were statistically higher than Red head and Titicaca. Temel and Yolcu (2020) reported that the quinoa plant heights according to different sowing dates varied between 50-125 cm. Geren (2015) indicated that the highest $\mathrm{PH}$ of quinoa was $94.1 \mathrm{~cm}$. In addition, Shah et al. (2020) reported that plant heights in different quinoa genotypes ranged from 97.7 to $153.3 \mathrm{~cm}$. Our results on plant heights closely conforms to previous researches using different quinoa cultivars and growing conditions (Fuentes and Bhargava, 2011; Tan and Temel, 2020). SD ranged from 9.55 to $10.45 \mathrm{~mm}$ according to cutting stages. The highest SD was obtained from the latest cutting stage while the lowest was obtained from the first cutting stage. SD among the genotypes varied 8.98-11.18 $\mathrm{mm}$. SD of Cherry vanilla, French vanilla and Mint vanilla were determined the higher than Red head and Titicaca. Similar differences among genotypes have been reported by other researchers. (Tan and Temel, 2020; Fuentes and Bhargava, 2011). Shah et al. (2020) was reported that the stem diameter of different quinoa genotypes was between 11.9-19.5 mm. This situation reveals that the stem diameter shows a significant variation depending on the genotype and environmental conditions.

Table 1. Plant height (PH), stem diameter (SD), dry forage yield (DFY), dry matter content (DM), water soluble carbohydrate (WSC) of quinoa as affected by cutting stages and genotypes.

\begin{tabular}{|c|c|c|c|c|c|}
\hline & $\begin{array}{c}\text { PH } \\
(\mathrm{cm})\end{array}$ & $\begin{array}{c}\text { SD } \\
(\mathbf{m m})\end{array}$ & $\begin{array}{c}\text { DFY } \\
\left(\mathbf{t ~ h a} \mathbf{a}^{-1}\right)\end{array}$ & $\begin{array}{l}\text { DM } \\
(\%)\end{array}$ & $\begin{array}{c}\text { WSC } \\
(\%)\end{array}$ \\
\hline \multicolumn{6}{|l|}{ Cutting stages } \\
\hline Flowering & $121.98^{\mathrm{B}+}$ & $9.55^{\mathrm{B}}$ & $10.29^{\mathrm{B}}$ & $23.41^{\mathrm{C}}$ & $8.47^{\mathrm{B}}$ \\
\hline Milky & $130.27^{\mathrm{AB}}$ & $10.29^{\mathrm{AB}}$ & $12.58^{\mathrm{B}}$ & $26.99^{\mathrm{B}}$ & $10.53^{\mathrm{A}}$ \\
\hline Dough & $135.84^{\mathrm{A}}$ & $10.45^{\mathrm{A}}$ & $15.47^{\mathrm{A}}$ & $31.66^{\mathrm{A}}$ & $11.83^{\mathrm{A}}$ \\
\hline$S L$ & $*$ & $*$ & $* *$ & $* * *$ & $* *$ \\
\hline \multicolumn{6}{|l|}{ Genotypes } \\
\hline Red Head & $128.69^{\mathrm{B}}$ & $9.32^{\mathrm{B}}$ & $11.72^{\mathrm{BC}}$ & $28.59^{\mathrm{A}}$ & $11.13^{\mathrm{B}}$ \\
\hline Cherry Vanilla & $133.76^{\mathrm{A}}$ & $10.63^{\mathrm{A}}$ & $13.05^{\mathrm{AB}}$ & $26.79^{\mathrm{B}}$ & $7.44^{\mathrm{C}}$ \\
\hline French Vanilla & $134.03^{\mathrm{A}}$ & $10.36^{\mathrm{A}}$ & $13.81^{\mathrm{A}}$ & $27.22^{\mathrm{B}}$ & $8.99^{C}$ \\
\hline Mint Vanilla & $136.26^{\mathrm{A}}$ & $11.18^{\mathrm{A}}$ & $13.85^{\mathrm{A}}$ & $25.98^{\mathrm{C}}$ & $8.76^{\mathrm{C}}$ \\
\hline Titicaca & $114.08^{\mathrm{B}}$ & $8.98^{\mathrm{B}}$ & $11.48^{\mathrm{C}}$ & $28.20^{\mathrm{A}}$ & $15.05^{\mathrm{A}}$ \\
\hline$S L$ & $* * *$ & $* * *$ & $* * *$ & $* * *$ & $* * *$ \\
\hline$S L^{i n t}$ & ns & ns & ns & $* * *$ & $* * *$ \\
\hline$S L^{\text {years }}$ & $* * *$ & $* * *$ & ns & $* * *$ & ns \\
\hline
\end{tabular}

$S L$ : Significance levels, $S L^{\text {int }}$ : Significance levels for interactions, **: Significant at $1 \%$ probability, ***: Significant at $0.1 \%$ probability, ns: nonsignificant, ${ }^{+}$Factor means shown with different letters in the same column are different from each other.

The effects of cutting stages and genotypes on dry forage yield (DFY) were statistically significant (Table 1). DFY obtained in flowering, milky and dough stages were $10.29,12.58$ and $15.47 \mathrm{~kg} \mathrm{ha}^{-1}$, respectively. While the highest DFY was determined in dough stage, the lowest value was found at flowering stage (Table 1). This result indicated that dry matter accumulation might be continued until the dough stage. Similarly, Liu et al. (2020) indicated that the biomass of quinoa increased to peak at grain filling stage and then decreased. Higher DFY was obtained from Cherry vanilla, French vanilla and Mint vanilla among genotypes. DFY of Red head and Titicaca were statistically lower than others. Dry forage yields reported in some studies were lower than that of our findings (Bañuelos, 1993; Kaya and Kizil-Aydemir, 2020) while Temel and Yolcu (2020) determined that DFY varied from 5.33 to $22.27 \mathrm{t} \mathrm{ha}^{-1}$ according to sowing dates and cutting stages. This situation reveals the importance of determining the correct cultural practices in the current ecological conditions. The current research results indicated that more than 15 tons of dry feed yield can be obtained per hectare from the quinoa harvested at the dough stage in Mediterranean climatic condition.

\section{Forage quality characteristics}

DM contents of quinoa genotypes were influenced by years (Table 1). Effects of both experimental factors and interaction on dry matter content (DM) and water soluble carbohydrate (WSC) were statistically significant (Table 1). DM contents varied between $22.57-34.06 \%$ among the interactions (Figure 2). The highest DM was obtained from dough stage in Red head genotype. Peiretti et al. (2013) and Temel and Yolcu (2020) reported that the DM contents at the different cutting stages of quinoa increased 
as the harvest time delayed. Asher et al. (2020) reported that the DM ratios of quinoa forage in dough stage was $28-30 \%$ like our results. WSC contents increased as the cutting stages delayed. Titicaca genotype gave superior results in term of WSC in all cutting stages (Figure 3). The highest WSC contents were determined in Titicaca genotype at dough stage. Soluble sugar is beneficial for plants to resist cold environments ( $\mathrm{Li}$ et al., 2018). Shah et al. (2020) was determined that WSC of different quinoa genotypes was between 19.5-49.1 $\mathrm{g} \mathrm{kg}^{-1}$. WSC contents obtained this study were determined higher than limited literature information. The occurrence of this result may be due to harvest times and genotype differences.

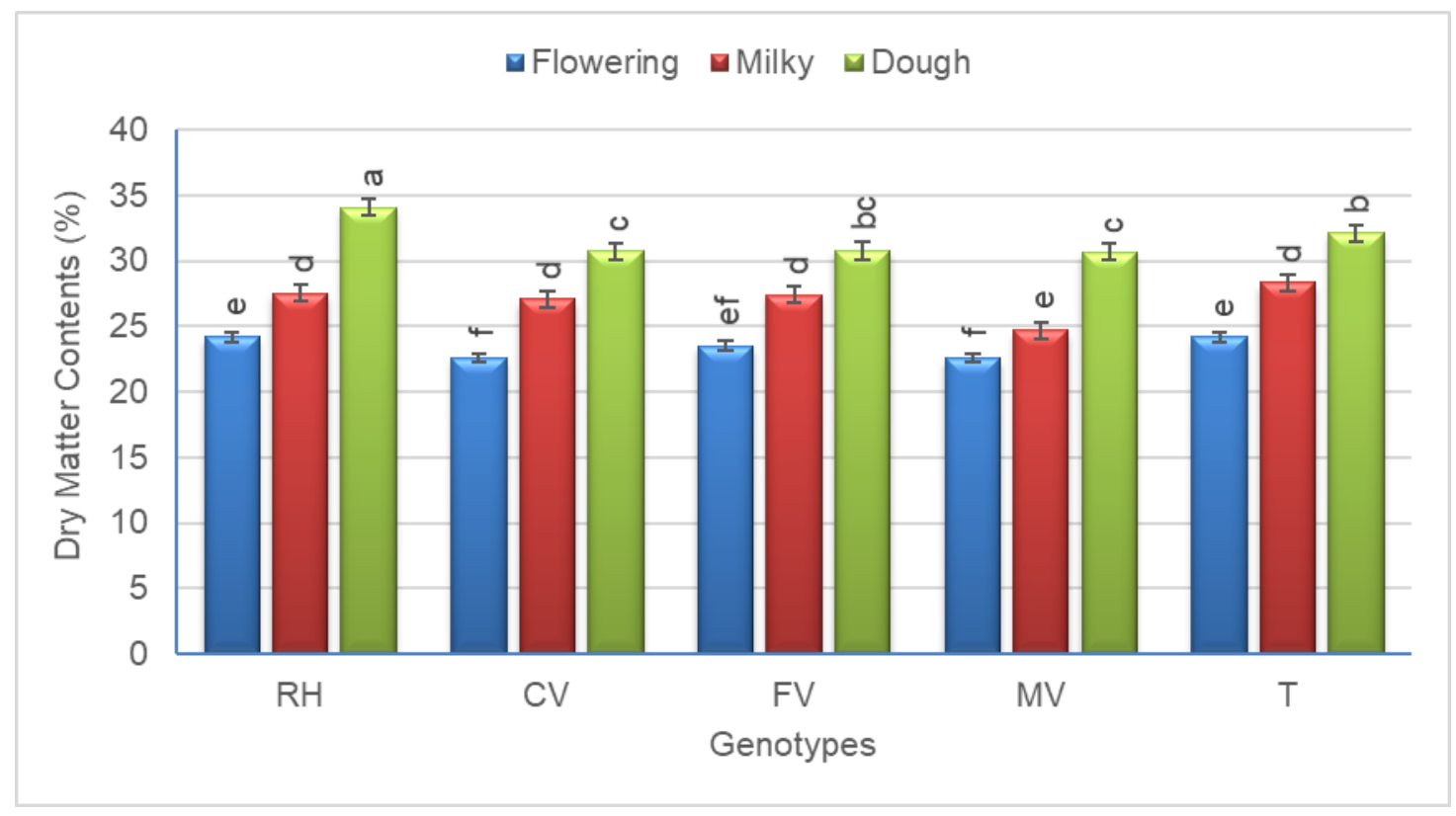

Figure 2. Effect of genotypes $\times$ cutting stages interaction on dry matter contents

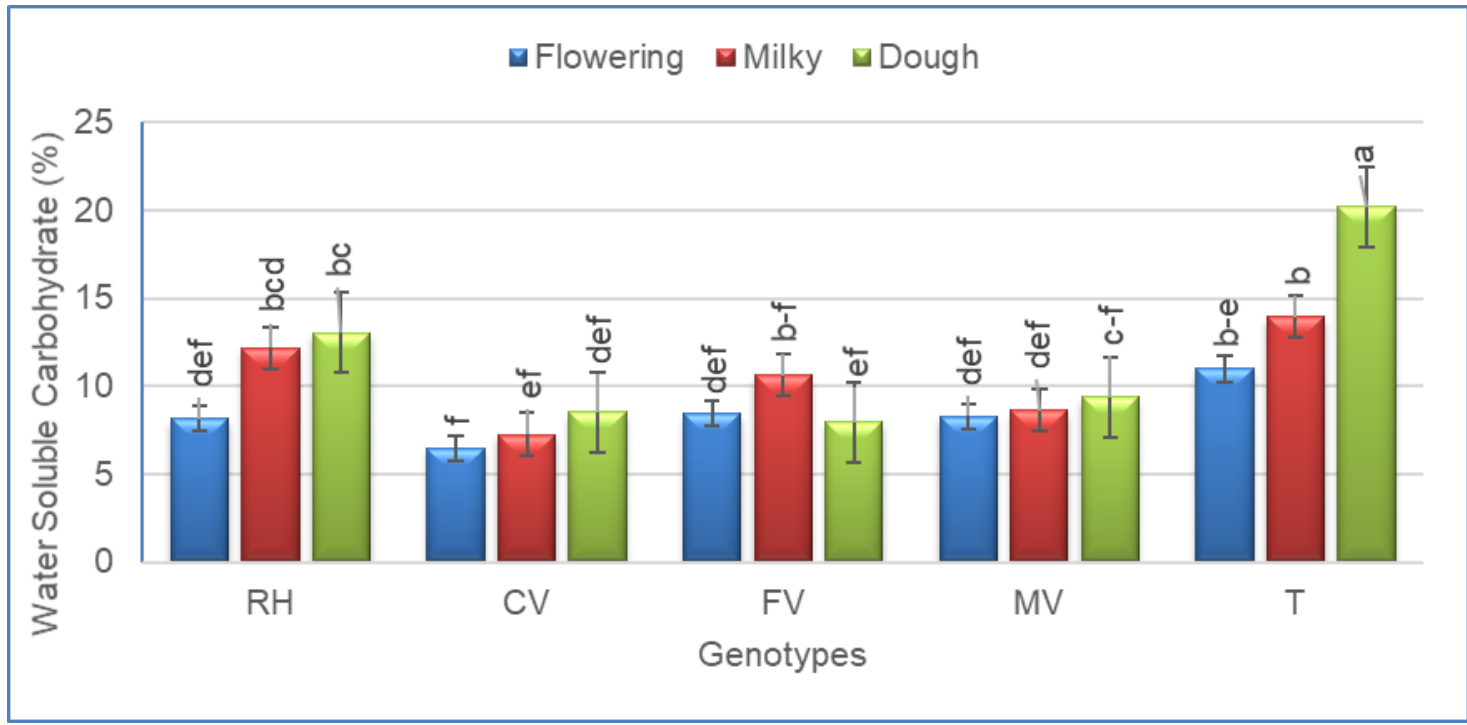

Figure 3. Effect of genotypes $\times$ cutting stages interaction on water soluble carbohydrate

Crude protein content was affected by years, cutting stages and genotypes, but not by $\mathrm{CS} \times \mathrm{G}$ interaction (Table 2 ). The highest crude protein content among the cutting stages was obtained from flowering stage (12.72\%), whereas the lowest value detected in dough stage $(10.10 \%)$. The highest crude protein content among the genotypes was determined in Titicaca $(11.63 \%)$, while the lowest value was obtained from Cherry vanilla (10.96\%). Some reported that the crude protein content of quinoa harvested at different phenological stages decreased as the plants were harvested late (Uke et al., 2017; Wei et al., 2018; Liu et al., 2020). The protein content values determined are consistent with the researches mentioned above. However, Temel and Yolcu (2020) reported higher protein contents for quinoa forage. The results of the research indicate that quinoa has a higher protein content than forage maize and sorghum (Atis et al., 2012; Zhang et al., 2017; Kaplan et al., 2019). 
Table 2. Crude protein (CP), NDF, ADF, ADL, condensed tannin contents of quinoa as affected by cutting stages and genotypes as means of two years.

\begin{tabular}{|c|c|c|c|c|c|}
\hline & $\begin{array}{l}\text { CP } \\
(\%)\end{array}$ & $\begin{array}{c}\text { NDF } \\
(\%) \\
\end{array}$ & $\begin{array}{c}\text { ADF } \\
(\%)\end{array}$ & $\begin{array}{c}\text { ADL } \\
(\%)\end{array}$ & $\begin{array}{l}\text { CT } \\
(\%) \\
\end{array}$ \\
\hline \multicolumn{6}{|l|}{ Cutting stages } \\
\hline Flowering & $12.72^{\mathrm{A}+}$ & 43.39 & $27.02^{\mathrm{A}}$ & 4.80 & $0.80^{\mathrm{B}}$ \\
\hline Milky & $11.14^{\mathrm{B}}$ & 42.89 & $26.08^{\mathrm{AB}}$ & 5.40 & $0.91^{\mathrm{B}}$ \\
\hline Dough & $10.10^{C}$ & 42.52 & $25.74^{\mathrm{B}}$ & 5.44 & $1.04^{\mathrm{A}}$ \\
\hline$S L$ & $* * *$ & $\mathrm{~ns}$ & $*$ & $\mathrm{~ns}$ & $* *$ \\
\hline \multicolumn{6}{|l|}{ Genotypes } \\
\hline Red Head & $11.19^{\mathrm{AB}}$ & $43.26^{\mathrm{A}}$ & $27.16^{\mathrm{A}}$ & 5.31 & $1.00^{\mathrm{A}}$ \\
\hline Cherry Vanilla & $10.96^{\mathrm{B}}$ & $44.21^{\mathrm{A}}$ & $26.94^{\mathrm{A}}$ & 5.09 & $1.03^{\mathrm{A}}$ \\
\hline French Vanilla & $11.51^{\mathrm{A}}$ & $43.56^{\mathrm{A}}$ & $26.48^{\mathrm{A}}$ & 5.45 & $0.76^{\mathrm{B}}$ \\
\hline Mint Vanilla & $11.33^{\mathrm{AB}}$ & $44.82^{\mathrm{A}}$ & $27.47^{\mathrm{A}}$ & 5.43 & $0.83^{\mathrm{B}}$ \\
\hline Titicaca & $11.63^{\mathrm{A}}$ & $38.82^{\mathrm{B}}$ & $23.35^{\mathrm{B}}$ & 4.80 & $0.97^{\mathrm{A}}$ \\
\hline$S L$ & $*$ & *** & $* * *$ & ns & $* * *$ \\
\hline$S L^{i n t}$ & $\mathrm{~ns}$ & $\mathrm{~ns}$ & ns & ns & $\mathrm{ns}$ \\
\hline$S L^{\text {years }}$ & $* * *$ & ns & ns & $\mathrm{ns}$ & $\mathrm{ns}$ \\
\hline
\end{tabular}

The NDF content was not affected by cutting stages (CS) and interactions $(\mathrm{CS} \times \mathrm{G})$ but affected by genotypes (Table 2). The highest NDF content was obtained from Mint vanilla genotype whereas the lowest NDF was found out Titicaca genotype (Table 2). Differences between quinoa genotypes in terms of NDF content have also been reported by Peiretti et al. (2013). Unlike the result of the present study, Uke et al. (2017) reported that NDF contents were increased with advanced plant maturity stage. Our results that the NDF content does not change with the advancement in harvest time can be explained by the increase in the grain ratio in the plant composition. The effects of cutting stages and genotypes were statistically significant in term of ADF content but the effect of $\mathrm{CS} \times \mathrm{G}$ interaction was insignificant (Table 2). The highest ADF among the cutting stages was obtained from flowering stage with $27.02 \%$, whereas the lowest ADF among the cutting stages was determined in dough stage. The highest ADF among the genotypes was obtained from Red head and Mint vanilla with $27.40 \%$. While among the genotypes the lowest ADF content was obtained from Titicaca, ADF contents of the others were statistically similar. Shah et al. (2020) reported that the ADF content in anthesis and grain filling stages of different quinoa genotypes ranged from 17.5 to $26.8 \%$ and 21.8 to $30.6 \%$, respectively. Peiretti et al. (2013) determined that the ADF content of quinoa in six different cutting stages varied significantly. The ADF values determined in this study are within the limits reported in the above-mentioned literature.

ADL contents were not influenced by experimental main factors and interaction (Table 2). ADL contents ranged from $4.80 \%$ to $5.45 \%$ among the quinoa genotypes. Although there was a tendency to increase in ADL content due to the advancing harvest time, this increase was found to be statistically insignificant. Peiretti et al. (2013) reported that the ADL content of quinoa according to plant growing stages of quinoa ranged from $4.66 \%$ to $6.74 \%$. Our results were similar to the results of Peiretti et al. (2013).

While the highest condensed tannin among the cutting stages was obtained from dough stage $(1.04 \%)$, the lowest value was determined in flowering stage $(0.80 \%)$. The highest condensed tannin among the genotypes was detected in Cherry vanilla (1.03\%), whereas the lowest CT value was found in French vanilla $(0.76 \%)$ (Table 2$)$. It was reported that if the condensed tannin content is between 5-10\%, this circumstance may cause unwillingness for feed in animals (Kamalak, 2007). Condensed tannin contents obtained this research were lower than the reported levels and it is thought that there will not be any adverse effects in terms of animal nutrition.

Crude ash content was affected by genotypes and $\mathrm{CS} \times \mathrm{G}$ interaction (Table 3). The highest crude ash obtained from dough stage of French vanilla (17.35\%), whereas the lowest crude ash was detected in milky stage of Cherry vanilla (15.49\%) (Figure 4). Liu et al. (2020) reported that the crude ash content of quinoa forage varied according to the phenological stages. Crude ash content of Red head genotype was significantly lower than those of others (Table 3). 
Table 3. Crude ash (CA), ether extract (EE), non-fiber carbohydrate (NFC) contents and relative feed value (RFV) of quinoa as affected by cutting stages and genotypes as means of two years.

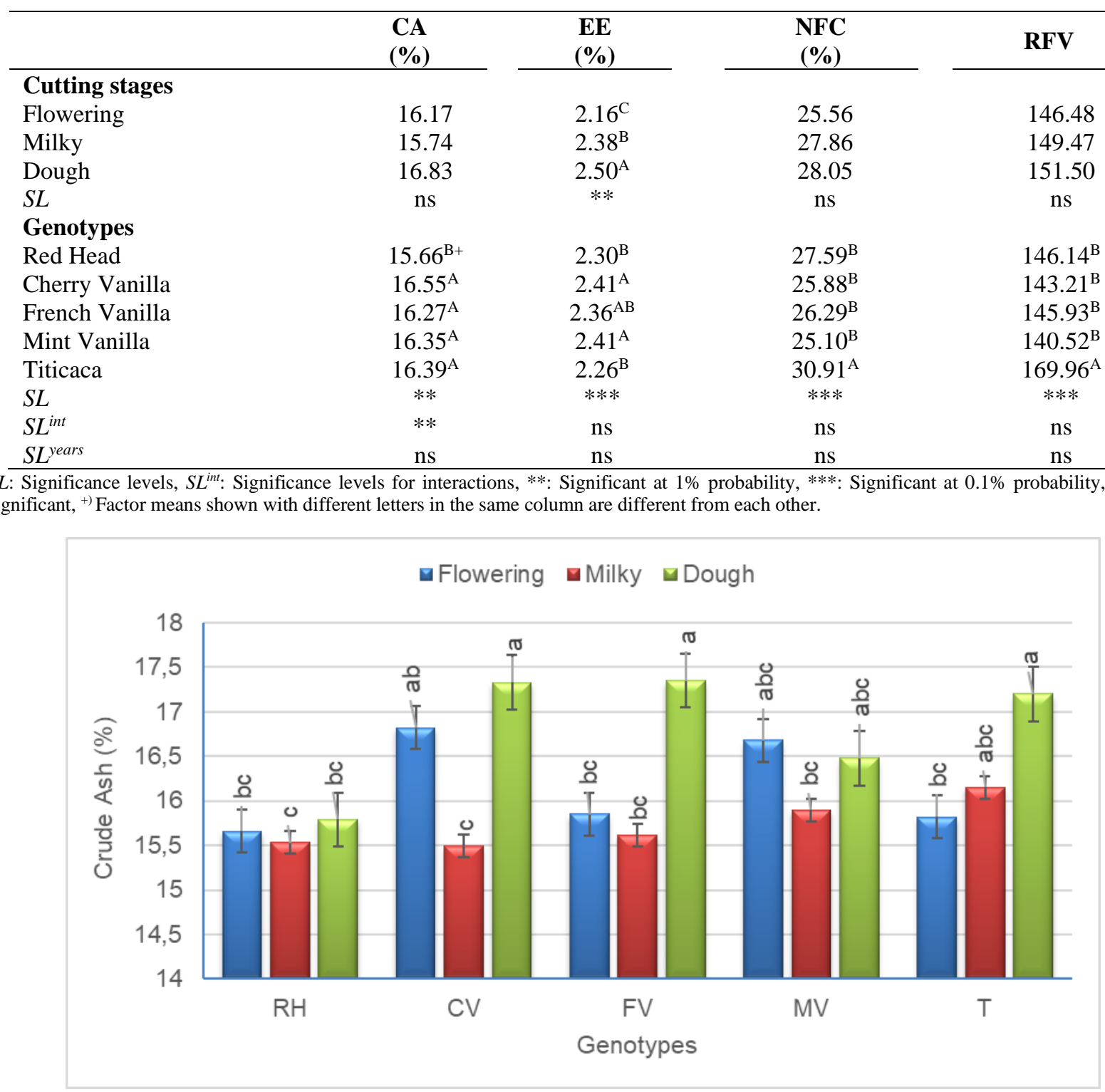

Figure 4. Effect of genotypes $\times$ cutting stages interaction on crude ash contents

The ether extract content was affected by cutting stages and genotypes (Table 3 ). The highest ether extract among the cutting stages was obtained from dough stage $(2.50 \%)$, while lowest values found at flowering stage $(2.16 \%)$. As the plants were harvested late, the ether extract content increased. On the contrary, Uke et al. (2017) found that ether extract contents of quinoa decreased with delayed cutting stage. This may be related to the proportional amount at the time of harvest of plant organs (Liu et al., 2020). The highest ether extract content among the genotypes was determined in Cherry vanilla and Mint vanilla $(2.41 \%)$, whereas the lowest value was found in Titicaca (2.26\%).

Non-fiber carbohydrate contents were only affected by genotypes. The highest non-fiber carbohydrate content among the genotypes was obtained from Titicaca $(30.91 \%)$, whereas the lowest value was obtained from
Mint vanilla (25.10\%) (Table 3). Liu et al. (2013) reported that the rumen fermentation patterns changed significantly in a positive direct with increased non-fiber carbohydrate contents. Non-fiber carbohydrate contents of quinoa forages have not been investigated by any study so far. Therefore, we think that these results about the non-fiber carbohydrate contents of quinoa are rather significant for literature.

The relative feed value was affected by genotypes, but not affected by cutting stages and $\mathrm{CS} \times \mathrm{G}$ interaction. The highest relative feed was obtained from Titicaca (169.96), whereas the lowest value was determined in Mint vanilla (140.52) (Table 3). Wei et al. (2018) reported that the relative feed value of quinoa forage was higher than 100 . Temel and Yolcu (2020) found that the relative feed value at different sowing times and harvesting stage (vegetative, beginning of flowering and full-flowering stages) of 
quinoa ranged from 143.8 to 227.3. Temel and Tan (2020) reported that the relative feed value of different quinoa genotypes varied from 169.06 to 188.32 . Also, Titicaca genotype used in this study as the plant material gave the highest relative feed value similar to our research.

\section{CONCLUSION}

The results of the research showed that suitable cutting stage of forage quinoa is dough stage for high yield and fodder quality. Late harvest caused an increase in yield. As a result, it was determined that more than 13 tons per hectare of dry forage yield can be obtained from quinoa in Mediterranean climatic conditions with the right harvest time and genotype combination. Generally, quality characteristics except protein content were not significantly affected or were positively affected by the delaying in harvest time. Among the 5 quinoa varieties used in the research, although Titicaca genotype produced higher quality forage, its yield was far behind other varieties. However, determining a minimum of $10 \%$ protein content and $140 \mathrm{RFV}$ value at all harvest times and in all genotypes has shown that quinoa is a good alternative roughage source. Due to its high yield and satisfactory quality, the Mint Vanilla genotype can be recommended for similar ecologies.

\section{ACKNOWLEDGEMENTS}

This study was supported by Hatay Mustafa Kemal University, Department of Scientific Research Projects with the project number: 19.M.004. Also, Plant material used in this study was obtained from Dr. Suleyman TEMEL from Igdir University. We thank to Hatay Mustafa Kemal University and Dr. Suleyman TEMEL.

\section{LITERATURE CITED}

AOAC, 2019. 21 $1^{\text {st }}$ edition. Official Methods of Analysis 2019 AOAC International.

Atis, I., O. Konuskan, M. Duru, H. Gozubenli and S. Yilmaz. 2012. Effect of harvesting time on yield, composition and forage quality of some forage sorghum cultivars. International Journal of Agriculture and Biology 14(6): 879886.

Asher, A., S. Galili, T. Whitney and L. Rubinovich. 2020. The potential of quinoa (Chenopodium quinoa) cultivation in Israel as a dualpurpose crop for grain production and livestock feed. Scientia Horticulturae 272: 109534.

Bañuelos, T.O. 1993. Evaluación forrajera de 18 variedades de quinua (Chenopodium quinoa Willd.) bajo condiciones de riego y temporal en Montecillo. (Doctoral Dissertation, Tesis De Licenciatura Universidad Autónoma Chapingo, Zonas Aridas).

Bazile, D. and F. Baudron. 2015. The dynamics of the global expansion of quinoa growing in view of its high biodiversity. In: State of the Art Report of Quinoa in the World in 2013, ed. Bazile, D., D. Bertero and C. Nieto, 42-55, FAO \& CIRAD, Rome.

Dubois, M., K.A. Gilles, J.K. Hamilton, P.A. Rebers and F. Smith. 1956. Colorimetric method for determination of sugars and related substances. Analytical Chemistry 28: 350356.

Dumanoglu, Z., D. Isik and H. Geren. 2016. Effect of different salt $(\mathrm{NaCl})$ concentrations on the grain yield and some yield components of quinoa (Chenopodium quinoa Willd.)
Journal of Agricultural Faculty of Ege University 53(2): 153159.

Fuentes, F. and A. Bhargava. 2011. Morphological analysis of quinoa germplasm grown under lowland desert conditions. Journal of Agronomy and Crop Science 197: 124-134.

Geren, H. 2015. Effect of different nitrogen levels on the grain yield and some yield components of quinoa (Chenopodium quinoa Willd.) under Mediterranean climatic conditions. Turkish Journal of Field Crops 20: 59-64.

Geren, H. and E. Gure. 2017. A preliminary study on the effect of different $\mathrm{N}$ and $\mathrm{P}$ levels on the grain yield and other yield components of quinoa (Chenopodium quinoa Willd.). Journal of Agricultural Faculty of Ege University 54(1): 1-8.

Geren, H., Y.T. Kavut and M. Altinbas. 2015. Effect of different row spacings on the grain yield and some yield characteristics of quinoa (Chenopodium quinoa Willd.) under Bornova ecological conditions. Journal of Agricultural Faculty of Ege University 52(1): 69-78.

Geren, H., Y.T. Kavut, G. Demiroglu Topcu, S. Ekren and D. Istipliler. 2014. Effects of different sowing dates on the grain yield and some yield components of quinoa (Chenopodium quinoa Wild.) grown under Mediterranean climatic conditions. Journal of Agricultural Faculty of Ege University 51(3): 297-305.

Kamalak, A. 2007. Feed additives and some chemical treatment to decrease the negative effect of condensed tannin. KSU Journal of Science and Engineering (10(2): 144-150.

Kaplan, M., K. Kara, A. Unlukara, H. Kale, S. BuyukkilicBeyzi, I.S. Varol, M. Kizilsimsek and A. Kamalak. 2019. Water deficit and nitrogen affects yield and feed value of sorghum sudangrass silage. Agricultural Water Management 218: $30-36$

Kaya, E. and S. Kizil Aydemir. 2020. Determining the forage yield, quality and nutritional element contents of quinoa cultivars and correlation analysis on these parameters. Pakistan Journal of Agricultural Sciences 57: 311-317.

Kir, A.E. and S. Temel. 2016. Determination of seed yield and some agronomical characteristics of different quinoa (Chenopodium quinoa Willd.) variety and populations under dry conditions of Igdir plain. Journal of the Institute of Science and Technology 6(4): 145-154.

Li, S., Y. Yang, Q. Zhang, N. Liu, Q. Xu and L. Hu. 2018. Differential physiological and metabolic response to low temperature in two zoysia grass genotypes native to high and low latitude. PLoS ONE. 13: e0198885.

Liu, D., X. Zhou, P. Zhao, M. Gao, H. Han and H. Hu. 2013. Effects of increasing non-fiber carbohydrate to neutral detergent fiber ratio on rumen fermentation and microbiota in goats. Journal of Integrative Agriculture 12(2): 319-326.

Liu, M., M. Yang and H. Yang. 2020. Biomass production and nutritional characteristics of quinoa subjected to cutting and sowing date in the mid-western China. Grassland Science 00: $1-10$.

Makkar, H.P.S., G. Gamble and K. Becker. 1999. Limitation of the butanol-hydrocloric acid-iron assay for bound condensed tannins. Food Chemistry 66: 129-133.

NRC, 2001. Nutrient requirements for cattle. ( $7^{\text {th }}$ rev. ed.), Natl. Acad. Sci., Washington, DC.

Peiretti, P.G., F. Gai and S. Tassone. 2013. Fatty acid profile and nutritive value of quinoa (Chenopodium quinoa Willd.) seeds and plants at different growth stages. Animal Feed Science and Technology 183: 56-61.

Rosero, O., D. Rosero and D. Lukešová. 2010. Determination of the capacities of farmers to adopt quinoa grain (Chenopodium quinoa willd) as potential feedstuff. Agricultura Tropica et Subtropica 43: 308-315. 
Shah, S.S., L. Shi, Z. Li, G. Ren, B. Zhou and P. Qin. 2020. Yield, agronomic and forage quality traits of different quinoa (Chenopodium quinoa Willd.) genotypes in Northeast China. Agronomy 10: 1908

Steel, R.G.D. and J.H. Torrie. 1980. Principles and Procedures of Statistics. McGaw-Hill Book Company, Inc. N.Y.

Tan, M. and S. Temel. 2017. Determination of dry matter yield and some properties of different quinoa genotypes grown in Erzurum and Igdir conditions. Igdir Univ Journal of Institute Science \& Technology 7: 257-263.

Tan, M. and S. Temel. 2019. Quinoa in Every Aspect: Importance, Use and Cultivation. Ankara, Turkey: IKSAD Publishing House.

Tan, M. and S. Temel. 2020. Determination of roughage production of different quinoa (Chenopodium quinoa Willd.) varieties in dry conditions of Eastern Anatolia. International Journal of Agriculture and Wildlife Science 6(3): 554-561.

Temel, S. and M. Tan. 2020. Evaluation of different quinoa varieties grown in dry conditions in terms of roughage quality properties. International Journal of Agriculture and Wildlife Science 6(2): 347-354.

Temel, S. and N. Surgun. 2019. The effect of different nitrogen and phosphorus doses on hay yield and quality of quinoa. Igdir Univ Journal of Institute Science \& Technology 9(3): $1785-1796$

Temel, S. and S. Yolcu. 2020. The effect of different sowing time and harvesting stages on the herbage yield and quality of quinoa (Chenopodium quinoa Willd.). Turkish Journal of Field Crops 25(1): 41-49.

Uke, O., H. Kale, M. Kaplan and A. Kamalak. 2017. Effects of maturity stages on hay yield and quality, gas and methane production of quinoa (Chenopodium quinoa Willd.). KSU Journal of Natural Sciences 20(1): 42-46.

Van Dyke, N.J. and P.N. Anderson. 2002. Interpreting a forage analysis. Alabama Cooperative Extension, Circular ANR890.

Van Soest, P.J., J.D. Robertson and B.A. Lewis. 1991. Methods for diatery fibre, neutral detergent fibre and non-starch polysaccharides in relation to animal nutrition. Journal of Dairy Science 74: 3583-3597.

Vega-Gálvez, A., Miranda, M., Vergara, J., Uribe, E., L. Puente and E.A. Martínez. 2010. Nutrition facts and functional potential of quinoa (Chenopodium quinoa Willd.), an ancient Andean grain: a review. Journal of the Science of Food and Agriculture 90: 2541-2547.

Wei, Y.M., F.R. Yang, W.Y. Liu, J. Huang, and Q. Jin. 2018. Regulation of nutrient accumulation and distribution in quinoa at different growth stages. Pratacultural Science 35(7): 1720-1727. (In chinese with English abstract).

Zhang, X., E.H. Ervin and A.J. Labranche. 2006. Metabolic defense responses of seeded bermudagrass during acclimation to freezing stress. Crop Science 46: 2598-2605. 